\title{
CHRONIC TOXICITY OF NEW PYRIDINE-N-OXIDE DERIVATIVES FOR TETRAHYMENA PYRIFORMIS W, DETERMINATION OF "STRUCTURE-TOXICITY", "CONCENTRATION-TIME-EFFECT" CORRELATION
}

\author{
O. Vasetska \\ L.I. Medved's Research Center of Preventive Toxicology, Food and Chemical Safety, \\ Ministry of Health, Ukraine (State Enterprise), Kyiv, Ukraine
}

\begin{abstract}
There is a considerable amount of work in the scientific literature on nonlinear ("paradoxical") effects, but their toxicological significance for the body is still poorly understood. Plant growth regulators are biologically active substances at the level of low and ultra-low doses and concentrations, they are widely used in agriculture. To date, the mechanisms of their toxic and specific effects on the body, the presence of "paradoxical" effects at low doses have not been sufficiently studied. Thus, it is important to further indepth study of the "concentration-time-effect" relationship under chronic exposure to the body, which will be important for understanding the general biological processes, developing approaches to hygienic regulation and risk assessment for human health and non-target environmental objects.
\end{abstract}

The Aim of the Research. Determine the dependence of "structure-toxicity", "concentration-time-effect" of plant growth regulators pyridine- $N$-oxide derivatives under conditions of chronic effects on the body of ciliates Tetrahymena pyriformis $W$.

Materials and Methods. The object of research was complexes of methyl derivatives of pyridine- $N$-oxide with organic acids and metal salts. Studies were performed on ciliates of Tetrahymena pyriformis $W$ in the stationary phase of growth. The chronic effect of plant growth regulators on ciliates was studied in a 96-hour experiment in the concentration range from $1 \times 10^{-2} \mathrm{M}$ to $1 \times 10^{-28} \mathrm{M}$. The initial number of ciliates in the sample was $20,000 \mathrm{cells} / \mathrm{ml}$ of culture medium. The samples were incubated in a dry air thermostat at $25^{\circ} \mathrm{C}$. After 24, 48, 72, 96 hours, the number of ciliates in different growth phases was determined. The experiments were performed in four replicates. The results of the research were subjected to mathematical processing by methods of variation statistics using the standard

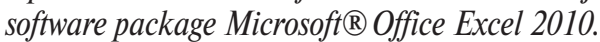

Results. It is shown that at a concentration of $1 \times 10^{-2}$ M investigated complexes of methyl derivatives of $N$-oxidepyridine with metal salts are more toxic than with organic acids. In the range of concentrations from $1 \times 10^{-4} \mathrm{M}$ to $1 \times 10^{-28} \mathrm{M}$ dependence "concentration-timeeffect" was not detected. Regardless of the concentration and duration of action, both inhibition and induction of ciliate population growth were observed. The change in the direction of the effect was observed at the level of high, low and ultralow concentrations.

Conclusions. 1. Under conditions of chronic exposure to the population of ciliates Tetrahymena pyriformis $W$, the rate of growth inhibition at a concentration of $1 \times 10^{-2} \mathrm{M}$, studied complexes $D G-377$ (Di-2,6-dimethylpyridine- $N$-oxide with $\left.\mathrm{ZnCl} \mathrm{l}_{2}\right), \quad \mathrm{DG}$-380 (Di-2,6-dimethylpyridine- $\mathrm{N}$-oxide with $\mathrm{ZnI} \mathrm{I}_{2}$ ), DG-387 (Di-2,6-dimethylpyridine- $\mathrm{N}$-oxide with $\mathrm{CoCl}_{2}$ ), DG-480 (2-methylpyridine$\mathrm{N}$-oxide with $\mathrm{CoCl}_{2}$ ), DG-471 (Di-2-methylpyridine- $\mathrm{N}$-oxide with) are more toxic than similar complexes with organic acids DG-361a (2,6-dimethylpyridine- $N$-oxide with succinic acid), DG-361 (Di-2,6-dimethylpyridine- $N$ - with succinic acid), DG-362 (2,6-dimethylpyridine- $N$-oxide with maleic acid), DG-349a (2-methylpyridine- $N$-oxide with succinic acid).

2. In the range of concentrations from $1 \times 10^{-4} \mathrm{M}$ to $1 \times 10^{-28} \mathrm{M}$, regardless of the concentration and time of action, there is both inhibition and induction of growth of the ciliate population. The change in the direction of the effect was observed at the level of high, low and ultralow concentrations. The growth of the ciliate population, depending on the concentrations of the studied substances and the time of exposure, was polymodal in nature.

3. According to the direction and severity of the effect on the growth of the ciliate population for DG-361a, DG-361, DG-377, DG-387, $D G-349 a$ and DG-480 is characterized mainly by an inhibitory effect. The stimulating effect was observed in some phases of growth and was moderate or weak. For DG-362, DG-380 and DG-471 is characterized by a pronounced stimulation of population growth of ciliates. Key Words: methyl derivatives of pyridine-N-oxide, ciliates, "structure-toxicity", "concentration-time-effect".

Introduction. It is known that some chemicals (olefins, biphenyls, heavy metals, herbicides, plant growth regulators (PGRs), some environmental pollutants, components of polymeric and paint materials, pharmacological agents), as well as physical factors (radiation, electromagnetic field) show high biological activity in low and extremely low doses and concentrations, sometimes the detected effects with decreasing dose are amplified or have a multidirectional effect. Enhancement of effects at the level of extremely low doses and concentrations is manifested at the molecular, subcellular, cellular, organ levels and the whole organism [1-10].

To date, bimodal or polymodal dependence "concentration-time-effect" has been revealed for many substances, including some PGRs, both on the body of plants, ciliates, and on the body of laboratory animals [7, 9-15]. 
The mechanisms of nonlinear ("paradoxical") effects for different test systems differ and depend on the interaction of enzymes with xenobiotics, metabolism and accumulation in different biological structures, the ability of xenobiotics to form toxic complexes with metals or chelates, the introduction of xenobiotics into the body primary localization in the cell and decompartmentalization, the state of signaling systems that regulate gene expression, destabilization of membranes and desynchronization of the expression of free radical processes (oxidative stress), tissue repair capabilities, the level of adaptive responses and more [5-7, 16-21] .

Despite the fact that in the scientific literature there is a significant amount of work on the "paradoxical" effects, but their toxicological significance for the body is still unclear.

Since PGRs are biologically active substances at low and ultra-low doses and concentrations, given their scale of use in agriculture, insufficient study of the mechanisms of their toxic and specific effects on the body, the presence of "paradoxical" effects at low doses, the urgent task of preventive toxicology is further in-depth study of the "concentration-timeeffect" dependence under conditions of chronic exposure to the body.

Accumulation of data on "paradoxical" effects and study of the mechanisms of PGR effects at the level of ultra-low doses will be important for understanding general biological processes, developing approaches to hygienic regulation and risk assessment for human health and non-target environmental objects.

The Aim of the Research. To determine the dependence of "structure-toxicity", "concentration-time-effect" of plant growth regulators derivatives of pyridine- $\mathrm{N}$-oxide under conditions of chronic effects on the body of ciliates Tetrahymena pyriformis $\mathrm{W}$.

Materials and Methods. The object of research were complexes of methyl derivatives of $\mathrm{N}$-pyridine oxide with organic acids and metal salts, synthesized at the Institute of Bioorganic Chemistry and Petrochemistry of the National Academy of Sciences of Ukraine: DG-361a (2,6-dimethylpyridine-N-oxide with succinic acid), DG-361 (Di-2,6dimethylpyridine- $\mathrm{N}$-oxide with succinic acid), DG-362 (2,6-dimethylpyridine-Noxide with maleic acid), DG-349a (2methylpyridine-N-oxide with succinic acid),
DG-377 (Di-2,6-dimethylpyridine-N-oxide with $\mathrm{ZnCl}_{2}$ ), DG-380 (Di-2,6-dimethylpyridine-N-oxide with $\mathrm{ZnI}_{2}$ ), DG-387 (Di-2,6dimethylpyridine-N-oxide with $\mathrm{CoCl}_{2}$ ), DG480 (2-methylpyridine-N-oxide with $\mathrm{CoCl}_{2}$ ), DG-471 (Di-2-methylpyridine-N-oxide with $\mathrm{CoI}_{2}$ ), which showed high cytokinin activity in crops and are recommended as plant growth regulators.

Studies conducted on Tetrahymena pyriformis $\mathrm{W}$ ciliates, which are widely used in toxicology as alternative test subjects to study the toxicity and mechanisms of action of many xenobiotics [22-25].

The chronic effect of these substances on the ciliate Tetrahymena pyriformis $\mathrm{W}$ was studied in accordance with the Guidelines in a 96-hour experiment in a wide range of concentrations from $1 \times 10^{-2} \mathrm{M}$ to $1 \times 10^{-28} \mathrm{M}$ [26]. The experiments were performed under sterile conditions. Infusoria in the stationary phase of growth in the amount of 20,000 individuals per $\mathrm{ml}$ of medium were inoculated in a nutrient medium with a certain volume of test substances, which were previously dissolved in a sterile culture medium. The samples were incubated for 96 hours in a dry air thermostat at $25^{\circ} \mathrm{C}$. After $24,48,72,96$ hours of incubation, the number of ciliates and the condition of infusoria in certain phases of their growth was determined - lag phase (24 hours), logarithmic phase (48 hours), stationary growth phase (72 and 96 hours). The experiments were performed in four replicates. The research results were subjected to mathematical processing by methods of variation statistics using the standard software package Microsoft ${ }^{\circledR}$ Office Excel 2010.

Results and Discussion. The effect of PGR DG-361a (complex of 2,6-dimethylpyridine$\mathrm{N}$-oxide with succinic acid) on the growth of the population of ciliates Tetrahymena pyriformis $\mathrm{W}$, depending on the concentration and duration of action is shown in Fig. $1(a, b)$.

As can be seen from Fig. 1 (a, b), DG-361a at a concentration of $1 \times 10^{-2} \mathrm{M}$ had a pronounced inhibitory effect on the growth of the ciliate population in all phases of growth - in the lag phase and the logarithmic phase of growth by $72,84 \%$ and $55,12 \%$, as well as in the stationary phase of growth (72 and $96 \mathrm{~h})$ by $41,01 \%$ and $77,98 \%$, respectively.

In the lag phase, the inhibitory effect on the growth of the ciliate population was main- 
tained in concentrations from $1 \times 10^{-4} \mathrm{M}$ to $1 \times 10^{-24} \mathrm{M}$ and at a concentration of $1 \times 10^{-28}$ $M$, the severity of the inhibitory effect did not depend on the active concentration and was highest in concentrations from $1 \times 10^{-8} \mathrm{M}$ to $1 \times 10^{-14} \mathrm{M}(35,80 \%-48,15 \%)$. Induction of ciliate growth was observed only at a concentration of $1 \times 10^{-26} \mathrm{M}(28,40 \%)$.

In the logarithmic phase of growth, a multidirectional effect on the growth of ciliates was revealed, so, in concentrations of $1 \times 10^{-4} \mathrm{M}$, $1 \times 10^{-6} \mathrm{M}, 1 \times 10^{-14} \mathrm{M}$, a slight induction of growth was observed (by $12,2 \%-18,11 \%$ ), in concentrations of $1 \times 10^{-10} \mathrm{M}, 1 \times 10^{-16} \mathrm{M}$, $1 \times 10^{-18} \mathrm{M}(10,24 \%-13,78 \%)$ revealed a slight inhibition of growth, in others - the growth of ciliates did not differ from the control.

In the stationary phase of growth $(72 \mathrm{~h})$ at a concentration of $1 \times 10^{-4} \mathrm{M}$ there was a slight induction of growth (by 26,27\%), in others significant differences in the growth of ciliates, relative to the control, were not detected.

In the stationary growth phase (96 hours) the impact on the growth of ciliates have wavy character

In the stationary growth phase (96 h) the effect on the growth of ciliates was wavy character, there was mainly inhibition of ciliate growth in concentrations of $1 \times 10^{-6} \mathrm{M}, 1 \times 10^{-12}$ M, $1 \times 10^{-14} \mathrm{M}$, respectively, by $57,80 \%$, $61,47 \%, 44,74 \%, 73,39 \%$. A slight stimulating effect on the growth of ciliates was found at a concentration of $1 \times 10^{-26} \mathrm{M}$ by $21,10 \%$.

As can be seen from the data above, under the influence of PGR DG-361a, the largest changes in ciliate growth occurred in the lag phase and stationary growth phase (96 h), and were characterized mainly by growth inhibition. The most pronounced inhibitory effect took place in the lag phase and stationary phase ( $96 \mathrm{~h}$ ) of ciliate growth, a slight stimulating effect - in the lag phase and stationary phase $(96 \mathrm{~h})$ at a concentration of $1 \times 10^{-26} \mathrm{M}$, logarithmic phase at concentrations of $1 \times 10^{-4}$ $\mathrm{M}$ and $1 \times 10^{-6} \mathrm{M}$ and stationary phase $(72 \mathrm{~h})-$ $1 \times 10^{-4} \mathrm{M}$. The growth of the ciliate population depending on the concentrations and exposure time was polymodal in nature.

The effect of PGR DG-361 (complex of Di-2,6-dimethylpyridine-N-oxide with succinic acid) on the growth of the population of ciliates Tetrahymena pyriformis $\mathrm{W}$ depending on the concentration and time of action is shown in Fig. 1 (c, d).
As can be seen from Fig. 1 (c, d), DG-361 at a concentration of $1 \times 10^{-2} \mathrm{M}$ had a pronounced inhibitory effect on the growth of ciliate populations in all phases of growth, with the most pronounced effect in the lag phase by $64,71 \%$, in other phases of growth on $36,9 \%-$ $45,2 \%$.

In the lag phase, the inhibitory effect on the growth of ciliates was also observed in concentrations of $1 \times 10^{-4} \mathrm{M}, 1 \times 10^{-6} \mathrm{M}, 1 \times 10^{-12} \mathrm{M}$, $1 \times 10^{-14} \mathrm{M}, 1 \times 10^{-20} \mathrm{M}$ and was $29,41 \%$, $17,65 \%, 26,47 \%, 32,35 \%, 29,41 \%$, respectively. A slight stimulating effect on growth was observed at concentrations of $1 \times 10^{-26} \mathrm{M}, 1 \times 10^{-28}$ $\mathrm{M}$ and was $17,65 \%$ and $14,71 \%$, respectively.

In the logarithmic phase, the inhibition of ciliate growth at a concentration of $1 \times 10^{-18} \mathrm{M}$ was greater than at a concentration of $1 \times 10^{-2} \mathrm{M}$ and was $46,43 \%$, at concentrations of $1 \times 10^{-4} \mathrm{M}$, $1 \times 10^{-10} \mathrm{M}$ and $1 \times 10^{-26} \mathrm{M}-$ did not exceed $14,29 \%$. The most pronounced stimulation of ciliate growth was detected under the influence of concentrations of $1 \times 10^{-20} \mathrm{M}$ and $1 \times 10^{-22} \mathrm{M}$ and relative to control was $35,71 \%$ and $22,62 \%$.

In the stationary phase of growth $(72 \mathrm{~h})$ at a concentration of $1 \times 10^{-18} \mathrm{M}$ inhibition of ciliate growth is most pronounced and was $16,76 \%$ more than at a high concentration of $1 \times 10^{-2} \mathrm{M}$. Stimulation of growth occurred at concentrations of $1 \times 10^{-8} \mathrm{M}, 1 \times 10^{-16} \mathrm{M}, 1 \times 10^{-22} \mathrm{M}-$ $1 \times 10^{-28} \mathrm{M}$, but it did not exceed $24,24 \%$.

In the stationary phase $(96 \mathrm{~h})$ the nature of the growth of ciliates is similar to 72 hours, with the same direction of changes in growth, but was less pronounced. Based on the data above, we can assume that in this period of growth prevails the inhibitory effect of PGR DG-361 on the growth of ciliates with the greatest effect at concentrations of $1 \times 10^{-2} \mathrm{M}$, $1 \times 10^{-18} \mathrm{M}$.

Thus, under the influence of PGR DG-361, regardless of the growth phase, the linearity of the inhibitory effect is observed only at high concentrations, it was greatest in the lag phase in the range of high concentrations, as well as in logarithmic and stationary growth phases at a concentration of $1 \times 10^{-18} \mathrm{M}$. The stimulating effect is manifested more at the level of ultralow concentrations. The growth of the ciliate population depending on the concentrations and time of exposure was polymodal in nature.

The effect of PGR DG-362 (2,6dimethylpyridine- $\mathrm{N}$-oxide with maleic acid) 
on the growth of the population of ciliates Tetrahymena pyriformis $\mathrm{W}$ depending on the concentration and time of action is shown in Fig. $1(d, e)$.

As can be seen from Fig.1 (d, e), PGR DG362 at a concentration of $1 \times 10^{-2} \mathrm{M}$ had a pronounced inhibitory effect on the growth of ciliate populations in all phases of growth, with the most pronounced effect in the lag phase and logarithmic $(76,62 \%$ and $83,74 \%$, respectively), stationary (72 and $96 \mathrm{~h}$ ) inhibition of ciliate growth was $47,68 \%$ and $58,20 \%$, respectively.

In the lag phase, starting from a concentration of $1 \times 10^{-2} \mathrm{M}$ to $1 \times 10^{-28} \mathrm{M}$ of DG-362 had a stimulating effect on the growth of the population of ciliates with the most pronounced effect $(141,56 \%-164,94 \%)$ in concentrations of $1 \times 10^{-4} \mathrm{M}, 1 \times 10^{-6} \mathrm{M}, 1 \times 10^{-14} \mathrm{M}, 1 \times 10^{-16} \mathrm{M}$, $1 \times 10^{-18} \mathrm{M}$ and $1 \times 10^{-26} \mathrm{M}$, changes in growth induction were polymodal in nature.

The logarithmic growth phase was also dominated by the stimulating effect on the growth of the ciliate population, but less: at a concentration of $1 \times 10^{-4} \mathrm{M}-$ by $101,63 \%$, $1 \times 10^{-16} \mathrm{M}$ - by $56,10 \%, 1 \times 10^{-18} \mathrm{M}-$ by $44,72 \%$, $1 \times 10^{-20} \mathrm{M}-$ by $30,08 \%$ and $1 \times 10^{-24} \mathrm{M}-$ by $25,20 \%$. With decreasing concentration, the stimulating effect decreased. Significant inhibitory effect $(36,59 \%)$ was observed only at extremely low concentrations of $1 \times 10^{-22} \mathrm{M}$.

In the stationary phase of growth $(72 \mathrm{~h})$ in most concentrations from $1 \times 10^{-4} \mathrm{M}$ to $1 \times 10^{-24}$ $\mathrm{M}$ there was a tendency to induce the growth of ciliates with the greatest effect at a concentration of $1 \times 10^{-24} \mathrm{M}(41,37 \%)$.

In the stationary phase of growth (96 h), compared with the concentration of $1 \times 10^{-2} \mathrm{M}$, the inhibitory effect in all concentrations was not pronounced and ranged from $4,82 \%$ to $22,83 \%$.

Thus, the effect of DG-362 on the body of ciliates at a concentration of $1 \times 10^{-2} \mathrm{M}$ was characterized by pronounced inhibition of ciliate growth in all growth phases, in the lag phase in the concentration range from $1 \times 10^{-2}$ $\mathrm{M}$ to $1 \times 10^{-28} \mathrm{M}$ was observed moderate or pronounced induction of ciliate growth, in the logarithmic and stationary phases of growth ( $72 \mathrm{~h}$ ) depending on the concentration there is a weak inhibition or growth stimulation, in the stationary growth phase $(96 \mathrm{~h})$ there is mostly unexpressed inhibition of ciliate population growth. The growth of the ciliate population depending on the concentrations and time of exposure was polymodal in nature.

The effect of PGR DG-377 (complex of Di-2,6-dimethylpyridine-N-oxide with $\mathrm{ZnCl}_{2}$ ) on the growth of the population of ciliates Tetrahymena pyriformis $\mathrm{W}$ depending on the concentration and time of action is given in Fig. $2(a, b)$.

As can be seen from Fig. 2 (a, b), DG-377 at a concentration of $1 \times 10^{-2} \mathrm{M}$ had a pronounced inhibitory effect on the growth of the ciliate population in all growth phases, with the most pronounced effect in the stationary growth phase (72 and 96 h) by $93,55 \%$ and $100 \%$ respectively.

In the lag phase and the logarithmic growth phase, DG-377 had a predominantly inhibitory effect on the growth of the ciliate population. Thus, in the lag phase, the most pronounced inhibition was observed at concentrations of $1 \times 10^{-2} \mathrm{M}, 1 \times 10^{-4} \mathrm{M}, 1 \times 10^{-16} \mathrm{M}$ $(88,73 \%, 49,30 \%$ and $38,03 \%$, respectively), in other concentrations - by $23,94 \%$ $15,49 \%$. At concentrations of $1 \times 10^{-14} \mathrm{M}$, $1 \times 10^{-18} \mathrm{M}, 1 \times 10^{-20} \mathrm{M}, 1 \times 10^{-28} \mathrm{M}$ population growth of ciliates did not differ from control. In the logarithmic phase, the inhibition of ciliate growth was almost at the same level and did not depend on the effective concentration as in the lag phase.

In the stationary phase of growth, despite the fact that at a concentration of $1 \times 10^{-2} \mathrm{M}$ almost completely stopped the growth of ciliates, at lower concentrations $(72 \mathrm{~h})$ growth inhibition was not pronounced, except for the concentration of $1 \times 10^{-12} \mathrm{M}(47,31 \%)$, at concentrations of $1 \times 10^{-22} \mathrm{M}, 1 \times 10^{-24} \mathrm{M}, 1 \times 10^{-26} \mathrm{M}$, weak stimulation of ciliate growth was observed with the greatest effect at a concentration of $1 \times 10^{-24} \mathrm{M}(37,63 \%)$. In the stationary phase of growth for 96 hours there was mainly stimulation of ciliate growth, with the greatest effect in concentrations of $1 \times 10^{-8} \mathrm{M}$ $(33,33 \%)$ and $1 \times 10^{-18} \mathrm{M}(55,21 \%)$.

Thus, the effect of DG-377 on the body of ciliates at a concentration of $1 \times 10^{-2} \mathrm{M}$ was characterized by pronounced inhibition of ciliate growth in all phases of growth. In the lag phase, logarithmic and stationary phases $(72$ h) DG-377 caused mostly moderate or weak growth inhibition, weak stimulation of ciliate growth in the stationary phase $(72 \mathrm{~h})$ occurred only in ultra-low concentrations $\left(1 \times 10^{-22} \mathrm{M}, 1 \times 10^{-24} \mathrm{M}, 1 \times 10^{-26} \mathrm{M}\right)$. In the sta- 


\section{2,6-dimethylpyridine-N-oxide with succinic acid (DG-361a)}
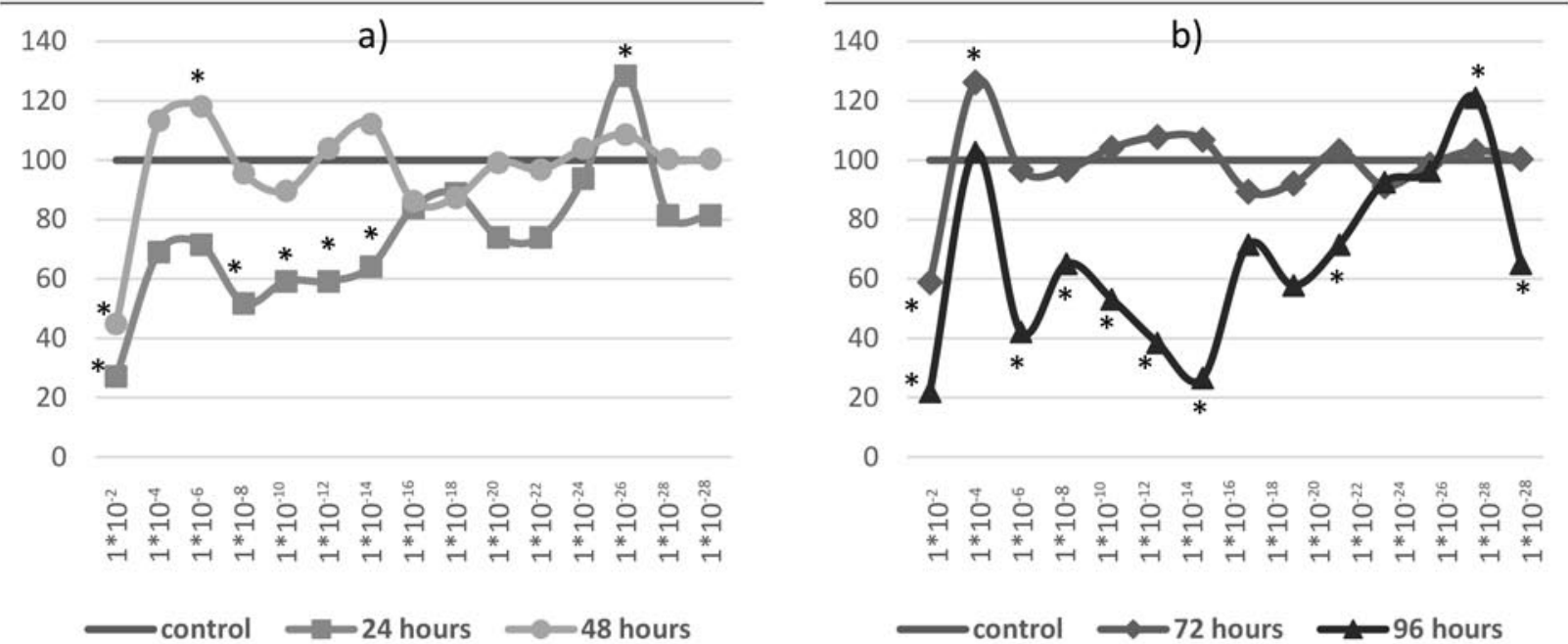

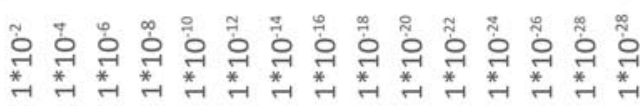

control -24 hours -48 hours

Di-2,6-dimethylpyridine-N-oxide with succinic acid (DG-361)
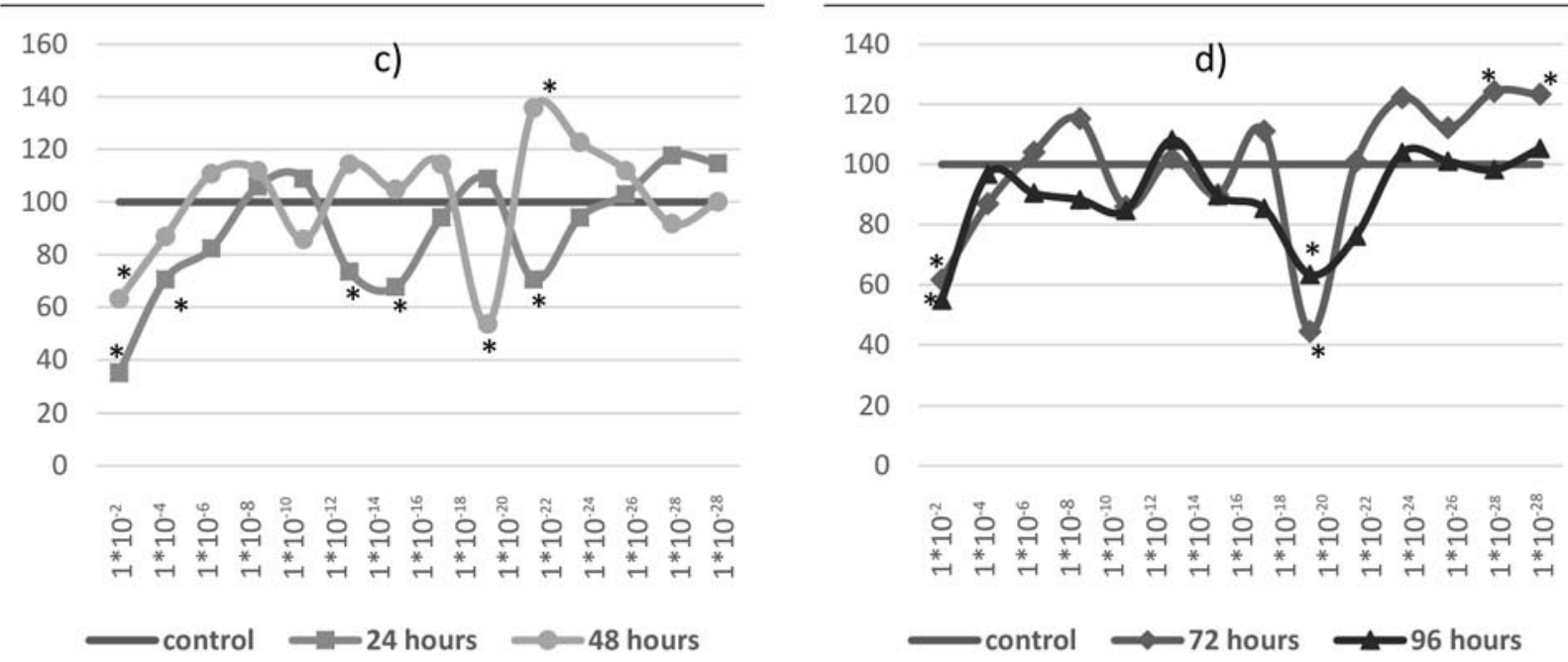

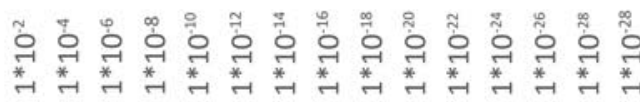

$\longrightarrow$ control -24 hours -48 hours

\section{2,6-dimethvlpvridine-N-oxide with maleic acid (DG-362)}
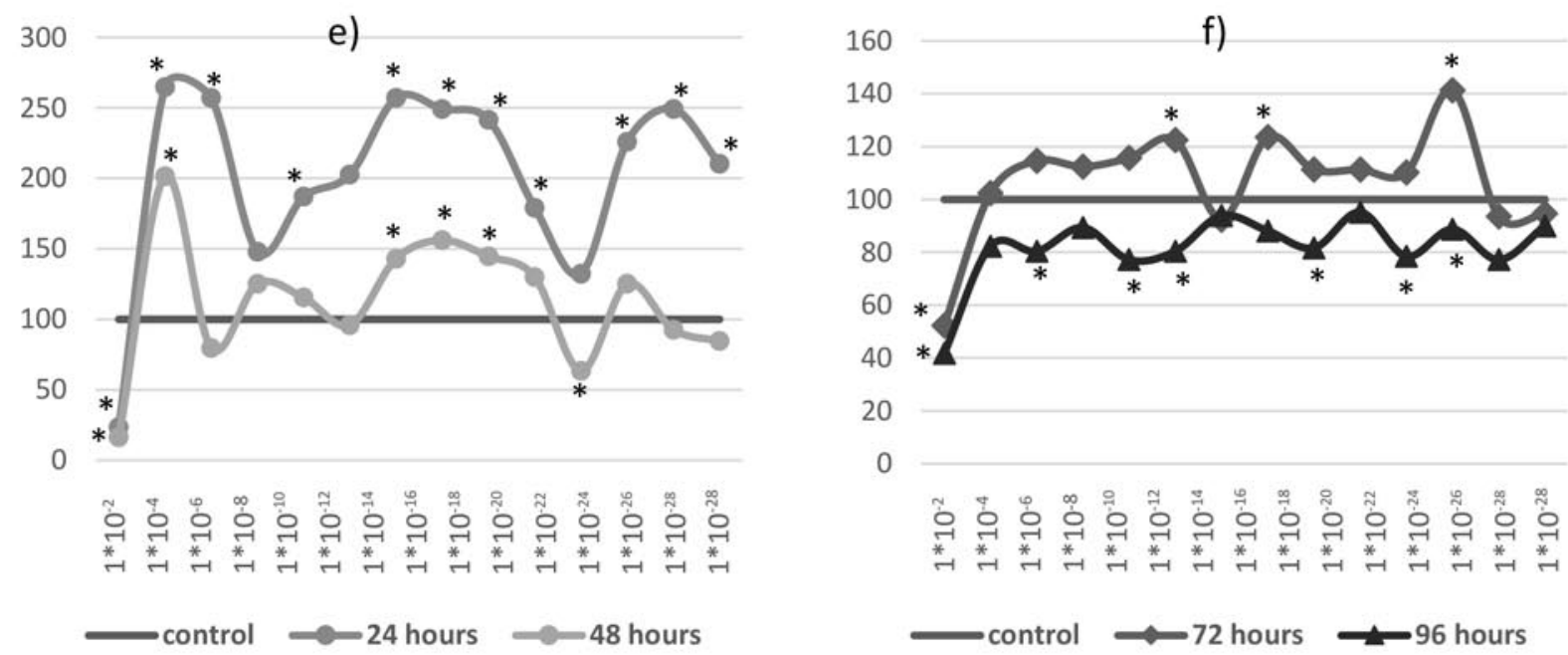

Fig.1. The effect of complexes of 2,6-dimethylpyridine-N-oxide with organic acids on the growth of ciliates in the conditions of chronic experiment (in\%):

a, b) - DG-361a; c, d) - DG-361; e, f) - DG-362 
Di-2,6-dimethylpyridine-N-oxide with $\mathrm{ZnCl}_{2}$ (DG-377)
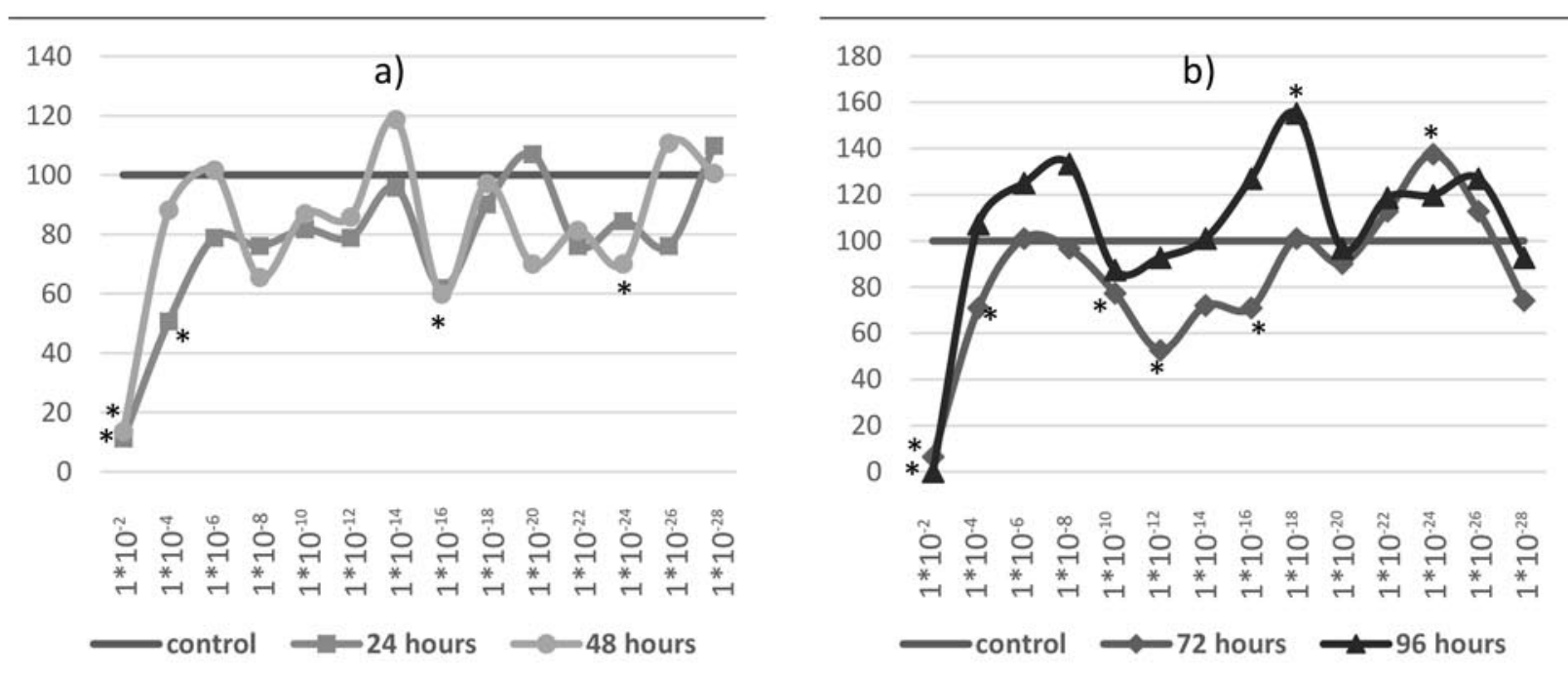

Di-2,6-dimethylpyridine-N-oxide with $\mathrm{ZnI}_{2}$ (DG-380)
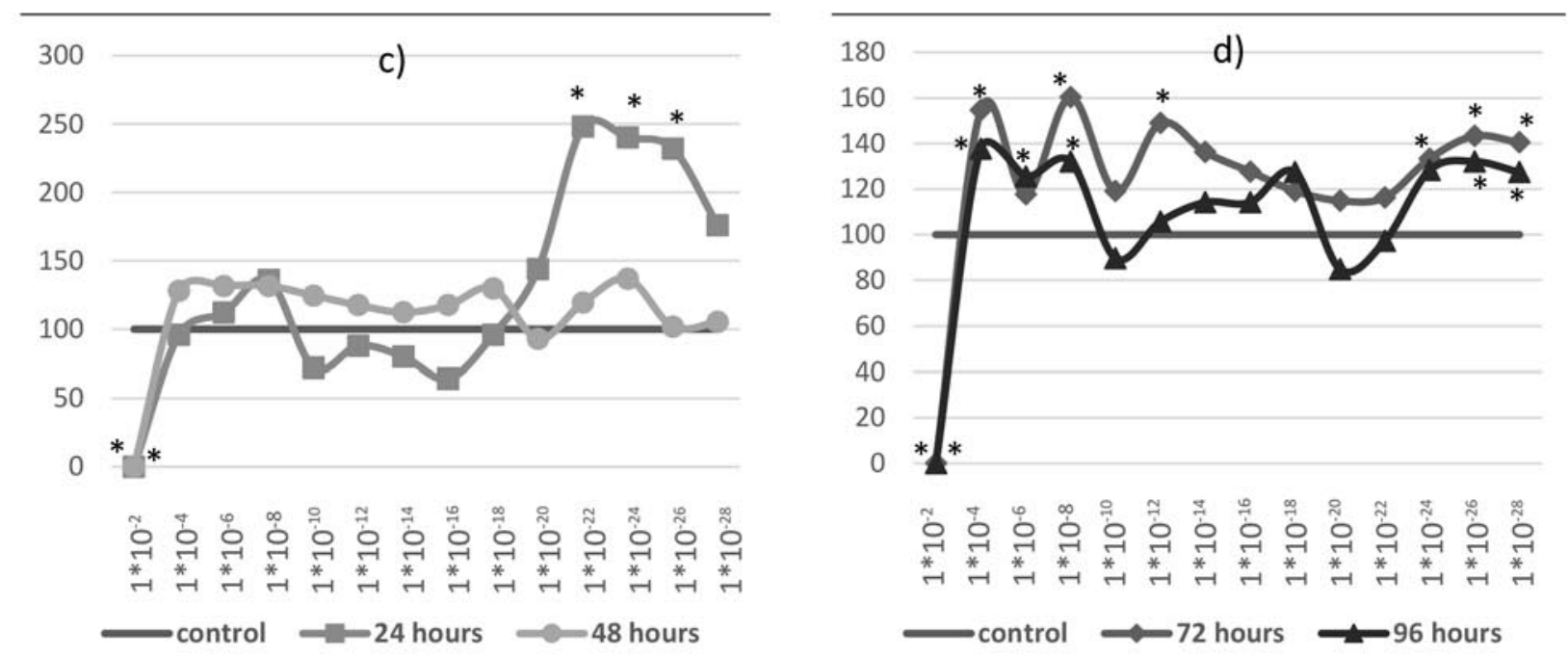

Di-2,6-dimethylpyridine-N-oxide with $\mathrm{CoCl}_{2}$ (DG-387)
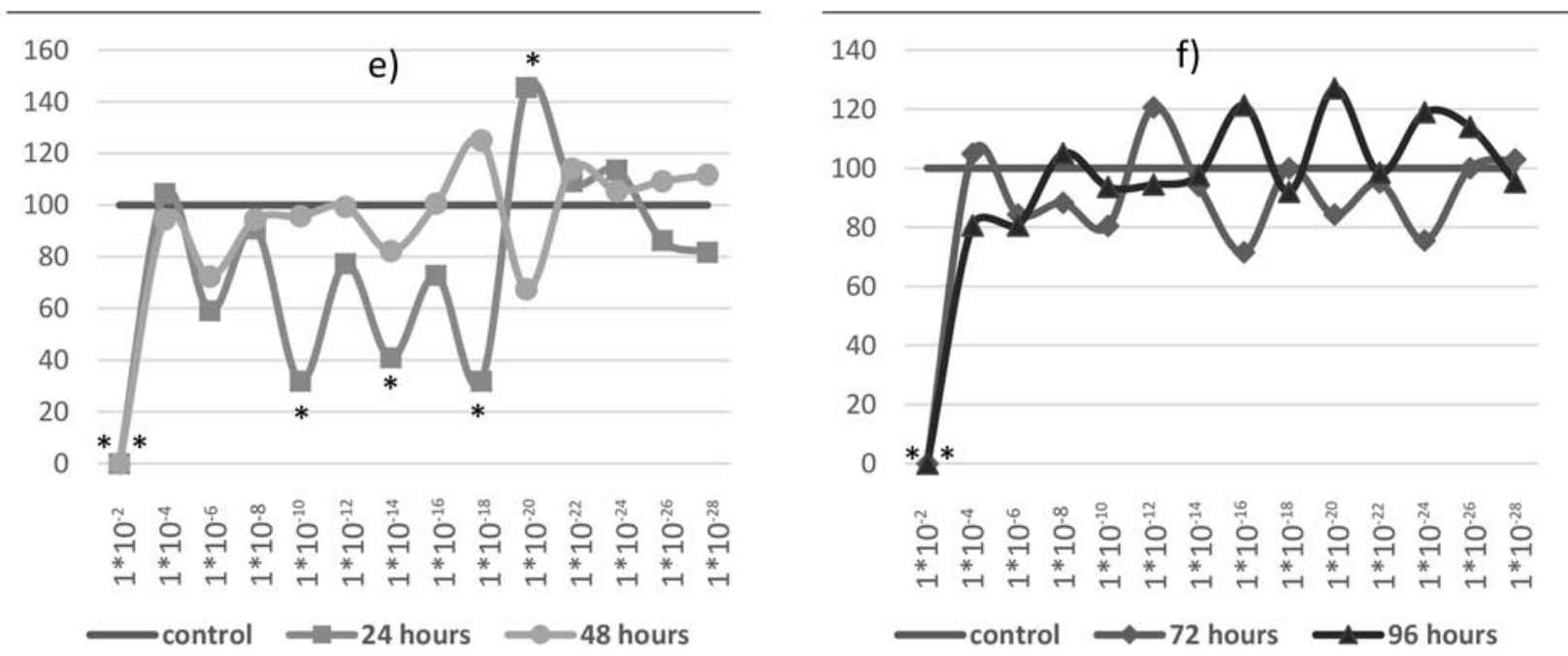

Fig.2. The effect of complexes of methyl derivatives of pyridine-N-oxide with metal salts on the growth of ciliates in the conditions of chronic experiment (in\%):

a, b) - DG-377, c, d) - DG-380, e, f) - DG-387 
tionary phase (96 h) there was stimulation of growth in different ranges of concentrations high, low and ultralow, with the most pronounced effect at a concentration of $1 \times 10^{-18} \mathrm{M}$. The growth of the ciliate population depending on the concentrations and exposure time was polymodal.

The effect of PGR DG-380 (complex of Di-2,6-dimethylpyridine-N-oxide with $\mathrm{ZnI}_{2}$ ) on the growth of the population of ciliates Tetrahymena pyriformis $\mathrm{W}$ depending on the concentration and time of action is shown in Fig. 2 (c, d).

As can be seen from Fig.2 (c, d), DG-380 at a concentration of $1 \times 10^{-2} \mathrm{M}$ had a pronounced inhibitory effect on the growth of the ciliate population in all phases of growth, growth inhibition was $100 \%$.

In the lag phase, inhibition of ciliate growth was observed in concentrations of $1 \times 10^{-10} \mathrm{M}-$ $1 \times 10^{-16} \mathrm{M}$ (from $12,00 \%$ to $36,00 \%$ ), as well as in concentrations of $1 \times 10^{-8} \mathrm{M}(36,00 \%)$, $1 \times 10^{-20} \mathrm{M}, 1 \times 10^{-22} \mathrm{M}, 1 \times 10^{-24} \mathrm{M}, 1 \times 10^{-26} \mathrm{M}$ and $1 \times 10^{-28} \mathrm{M}$, respectively by $44,00 \%, 148,00$ $\%, 140,00 \%, 132,00 \%$ and $76,00 \%$.

In the logarithmic phase of growth, starting from concentrations from $1 \times 10^{-4} \mathrm{M}$ to $1 \times 10^{-18}$ $\mathrm{M}$ and $1 \times 10^{-22} \mathrm{M}$ and $1 \times 10^{-24} \mathrm{M}$, there was a pronounced stimulation of ciliate growth (from $12,28 \%$ to $36,84 \%$ ), which did not depend on the current concentration. At other concentrations, ciliate growth was at the control level.

In the stationary phase of growth $(72 \mathrm{~h})$ there was only growth stimulation, which was most pronounced in concentrations of $1 \times 10^{-4} \mathrm{M}$, $1 \times 10^{-8} \mathrm{M}, 1 \times 10^{-12} \mathrm{M}, 1 \times 10^{-26} \mathrm{M}$ and $1 \times 10^{-28}$ $\mathrm{M}$ and was $54,61 \%, 60,28 \%, 48,94 \%, 43,26 \%$ and $40,43 \%$, respectively. In the stationary phase of growth $(96 \mathrm{~h})$ the stimulating influence on growth of ciliates which was expressed less than in 72 hours prevailed. The most pronounced stimulating effect was at concentrations of $1 \times 10^{-4} \mathrm{M}(37,74 \%), 1 \times 10^{-8} \mathrm{M}$ $(32,08 \%), 1 \times 10^{-26} \mathrm{M}(32,08 \%)$. Slight growth inhibition was observed at concentrations of $1 \times 10^{-10} \mathrm{M}$ and $1 \times 10^{-20} \mathrm{M}(10,38 \%$ and $15,09 \%$, respectively).

Thus, DG-380 is characterized by stimulation of population growth of ciliates in all phases of growth with the greatest effect in concentrations from $1 \times 10^{-22}$ to $1 \times 10^{-28} \mathrm{M}$ in the lag phase and in concentrations of $1 \times 10^{-4} \mathrm{M}$, $1 \times 10^{-8} \mathrm{M}, 1 \times 10^{-12} \mathrm{M}$ in the stationary growth phase $(72 \mathrm{~h})$. At a concentration of $1 \times 10^{-2} \mathrm{M}$ there was a pronounced inhibition of ciliate growth in all phases of development, less pronounced but significant growth inhibition was observed at a concentration of $1 \times 10^{-16} \mathrm{M}$ in the lag phase of growth. The growth of the ciliate population depending on the concentrations and time of exposure was polymodal in nature.

The effect of PGR DG-387 (complex of Di-2,6-dimethylpyridine-N-oxide with $\mathrm{CoCl}_{2}$ ) on the growth of the population of ciliates Tetrahymena pyriformis $\mathrm{W}$ depending on the concentration and time of action is shown in Fig. 2 (d, e).

As can be seen from Fig. 2 (d, e), DG-387 at a concentration of $1 \times 10^{-2} \mathrm{M}$ had a pronounced inhibitory effect on the growth of the ciliate population in all phases of growth, the inhibition was $100 \%$.

In the lag phase, logarithmic and stationary $(72 \mathrm{~h})$ growth phases at a concentration of $1 \times 10^{-4} \mathrm{M}$ population growth of ciliates was at the level of control, in the stationary growth phase (96 h) - a slight inhibition of growth (by $19,40 \%)$, which was maintained at the same level and at a concentration of $1 \times 10^{-6} \mathrm{M}$.

In the lag phase in concentrations from $1 \times 10^{-6} \mathrm{M}$ to $1 \times 10^{-18} \mathrm{M}, 1 \times 10^{-26} \mathrm{M}$ and $1 \times 10^{-28} \mathrm{M}$ DG-387 had an inhibitory effect on the growth of the population of ciliates with the greatest effect at concentrations of $1 \times 10^{-10} \mathrm{M}, 1 \times 10^{-14} \mathrm{M}$ and $1 \times 10^{-18} \mathrm{M}(68,18 \%, 59,09 \%$ and $68,18 \%$, respectively). At a concentration of $1 \times 10^{-20} \mathrm{M}-$ moderate stimulation of ciliate growth $(45,45 \%)$.

In the logarithmic growth phase at concentrations of $1 \times 10^{-6} \mathrm{M}$ and $1 \times 10^{-20} \mathrm{M}$ revealed inhibition of ciliate growth by $27,61 \%$ and $32,52 \%$, respectively, and stimulation of ciliate growth at a concentration of $1 \times 10^{-18} \mathrm{M}$ by $25,15 \%$. At other concentrations, the effects were not significant.

In the stationary phase of growth (72 and $96 \mathrm{~h}$ ) in most of the studied concentrations the effect was with the opposite sign. Therefore, growth inhibition $(11,76 \%$ to $28,43 \%)$ prevailed for 72 hours of the study, except for a concentration of $1 \times 10^{-12} \mathrm{M}$, where growth was stimulated by $20,59 \%$. At 96 hours at concentrations of $1 \times 10^{-16} \mathrm{M}, 1 \times 10^{-20} \mathrm{M}, 1 \times 10^{-24} \mathrm{M}$ and $1 \times 10^{-26} \mathrm{M}$, weak growth stimulation was observed (from $13,98 \%$ to $27,00 \%$ ). In other concentrations, the growth of ciliates is at the control level.

Thus, DG-387 in all phases of growth of the 
population of ciliates at a concentration of $1 \times 10^{-2} \mathrm{M}$ has a pronounced toxic effect, as evidenced by the complete inhibition of their growth. Depending on the growth phase, the inhibitory effect is manifested in different ways: the most pronounced in the lag phase and the least pronounced in the stationary growth phase. Under the action of DG-387 in all phases of growth there is a change in the sign of the effect and this is most characteristic of the stationary phase. Mostly weak stimulation of ciliate growth is observed in individual concentrations at low or ultra-low levels in all phases. The growth of the ciliate population depending on the concentrations and time of exposure was polymodal in nature.

The effect of PGR DG-349a (complex of 2-methylpyridine-N-oxide with succinic acid) on the growth of the population of ciliates Tetrahymena pyriformis $\mathrm{W}$ depending on the concentration and duration of action is shown in Fig. 3 (a, b).

As can be seen from Fig. 3 (a, b), the effect of PGR DG-349a on population growth of ciliates did not depend on the current concentration. Inhibitory action prevailed over stimulating. Weak or moderate inhibition of ciliate growth was observed in all growth phases, with the greatest effect at a concentration of $1 \times 10^{-8}$ $\mathrm{M}$ in the lag phase $(68,75 \%)$.

Stimulation of ciliate growth in the lag phase occurred at concentrations of $1 \times 10^{-6} \mathrm{M}$, $1 \times 10^{-14} \mathrm{M}$ and $1 \times 10^{-28} \mathrm{M}$ and was $53,13 \%$, $18,75 \%, 25,0 \%$, respectively. In the logarithmic phase - only at a concentration of $1 \times 10^{-16} \mathrm{M}$ $(27,27 \%)$. In the stationary growth phase (72 h) slight stimulation was detected at concentrations of $1 \times 10^{-16} \mathrm{M}$ and $1 \times 10^{-18} \mathrm{M}$ $(20,17 \%$ and $16,74 \%$, respectively) and the stationary growth phase $(96 \mathrm{~h})$ at concentrations of $1 \times 10^{-14}, 1 \times 10^{-16}$ and $1 \times 10^{-28} \mathrm{M}$ $(30,61 \%, 29,80 \%$ and $26,53 \%)$.

Thus, DG-349a is characterized mainly by inhibition of ciliate population growth with the most pronounced effect at a concentration of $1 \times 10^{-8} \mathrm{M}$. The severity of the effect did not depend on the concentration and was more pronounced in the lag phase and stationary growth phase $(72 \mathrm{~h})$. Stimulation occurred in all growth phases and was weak in most concentrations, except for the concentration of $1 \times 10^{-6} \mathrm{M}$ in the lag phase, where moderate induction of ciliate population growth was observed.
The change in the direction of the effect occurred at the level of high, low, and ultralow concentrations. The growth of the ciliate population depending on the concentrations and time of exposure was polymodal in nature.

The effect of PGR DG-480 (complex of 2-methylpyridine-N-oxide with $\mathrm{CoCl}_{2}$ ) on the growth of the population of ciliates Tetrahymena pyriformis $\mathrm{W}$ depending on the concentration and time of action (see Fig. 3 (c, d)).

As can be seen from Fig. 3 (c, d), DG-480 at a concentration of $1 \times 10^{-2} \mathrm{M}$ depending on the time of action has a pronounced toxic effect on the population of ciliates, which causes inhibition of ciliate growth in the lag phase by $72,09 \%$, in others - by $100 \%$. With a decrease in concentration to $1 \times 10^{-4} \mathrm{M}$, the inhibitory effect is leveled (in the lag phase) or slightly expressed in other phases of growth. In the lag phase in the concentration range of $1 \times 10^{-6} \mathrm{M}$ to $1 \times 10^{-20} \mathrm{M}$ is more pronounced than in the logarithmic growth phase, and this suggests that over time, the inhibition of ciliate growth decreases. At the level of ultra-low concentrations $\left(1 \times 10^{-26} \mathrm{M}\right)$ there is a change in the direction of the effect: in the lag phase growth stimulation, in the logarithmic growth phase - inhibition of ciliate growth.

In the stationary phase of growth, both inhibition and stimulation of ciliate growth are weak. The most significant inhibition of ciliate growth was observed in the stationary phase (72 $\mathrm{h}$ ) at concentrations of $1 \times 10^{-8} \mathrm{M}, 1 \times 10^{-10} \mathrm{M}$, $1 \times 10^{-14} \mathrm{M}, 1 \times 10^{-20} \mathrm{M}$ and $1 \times 10^{-22} \mathrm{M}$ (from $20,72 \%$ to $29,43 \%$ ), after 96 hours - at a concentration of $1 \times 10^{-8} \mathrm{M}$ by $31,58 \%$. Stimulation of ciliate growth was observed in the stationary phase after 72 hours at a concentration of $1 \times 10^{-16} \mathrm{M}$ by $22,52 \%$, and 96 hours at a concentration of $1 \times 10^{-14} \mathrm{M}$ by $27,63 \%$ and $1 \times 10^{-24} \mathrm{M}$ by $14,47 \%$.

Thus, DG-480 is characterized mainly by inhibition of growth of the ciliate population, with the most pronounced effect at a concentration of $1 \times 10^{-2} \mathrm{M}$. The severity of the effect did not depend on the concentration and time of exposure and was more pronounced in the lag phase of growth. Stimulation of ciliate population growth occurred in the lag phase and stationary growth phase and was weak. The change in the direction of the effect was observed at the level of low and ultralow concentrations. The growth of the ciliate population depending on the concentrations and time of exposure was polymodal in nature. 


\section{2-methylpyridine-N-oxide with succinic acid (DG-349a)}
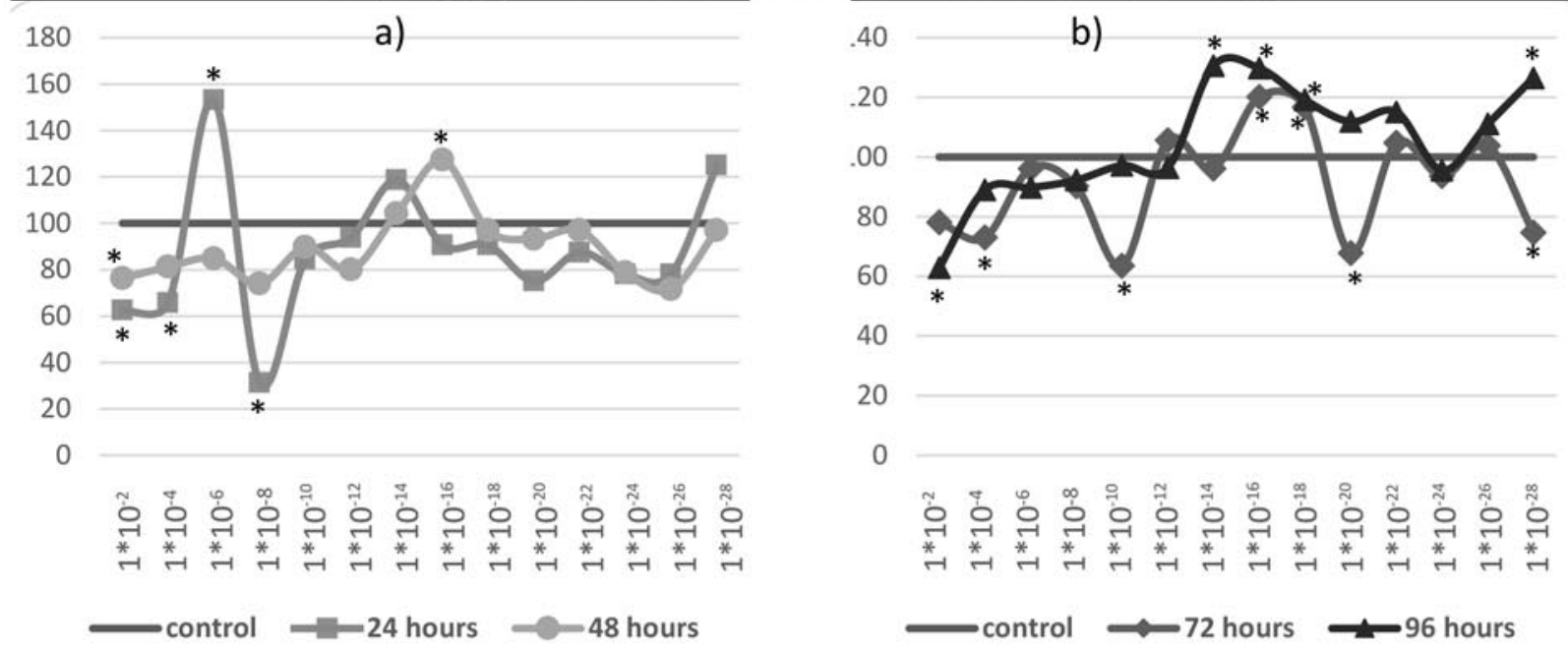

2-methylpyridine-N-oxide with $\mathrm{CoCl}_{2}$ (DG-480)
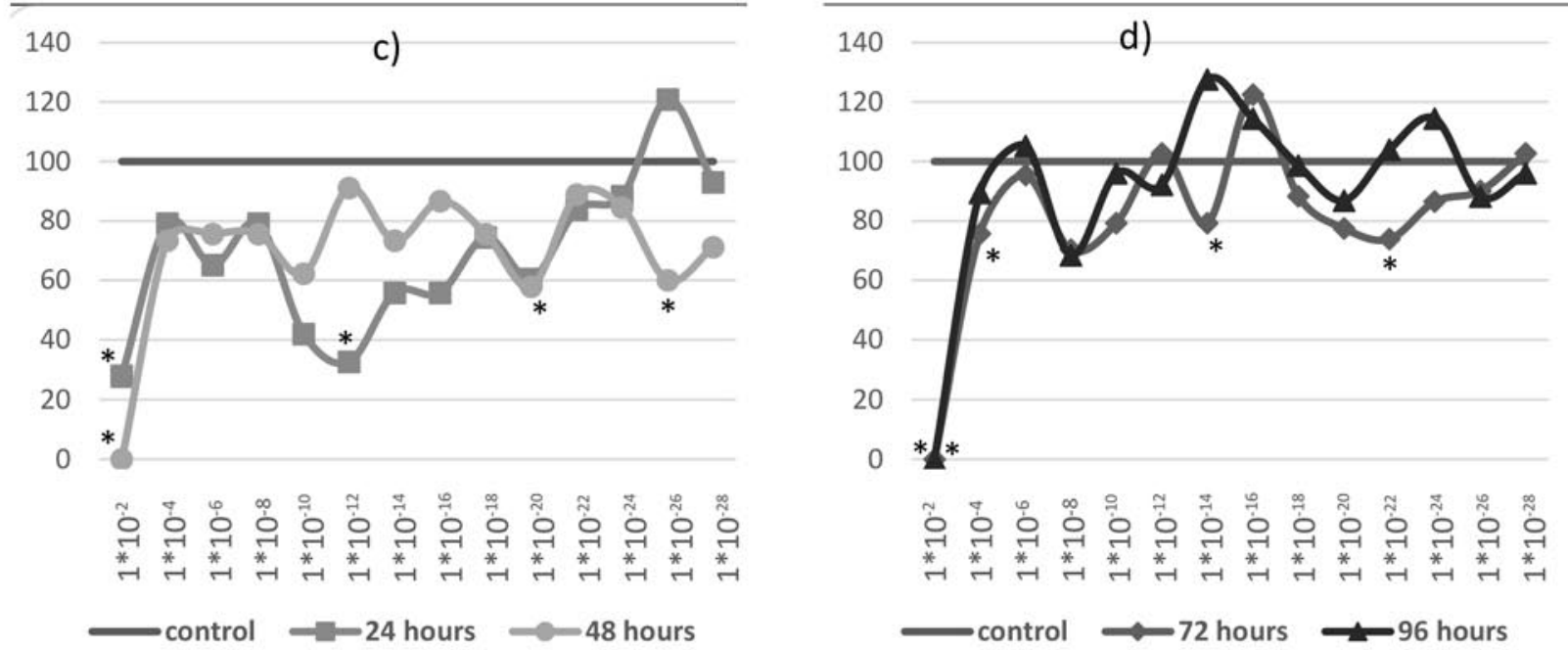

Di-2-methylpyridine-N-oxide with $\mathrm{CoI}_{2}$ (DG-471)
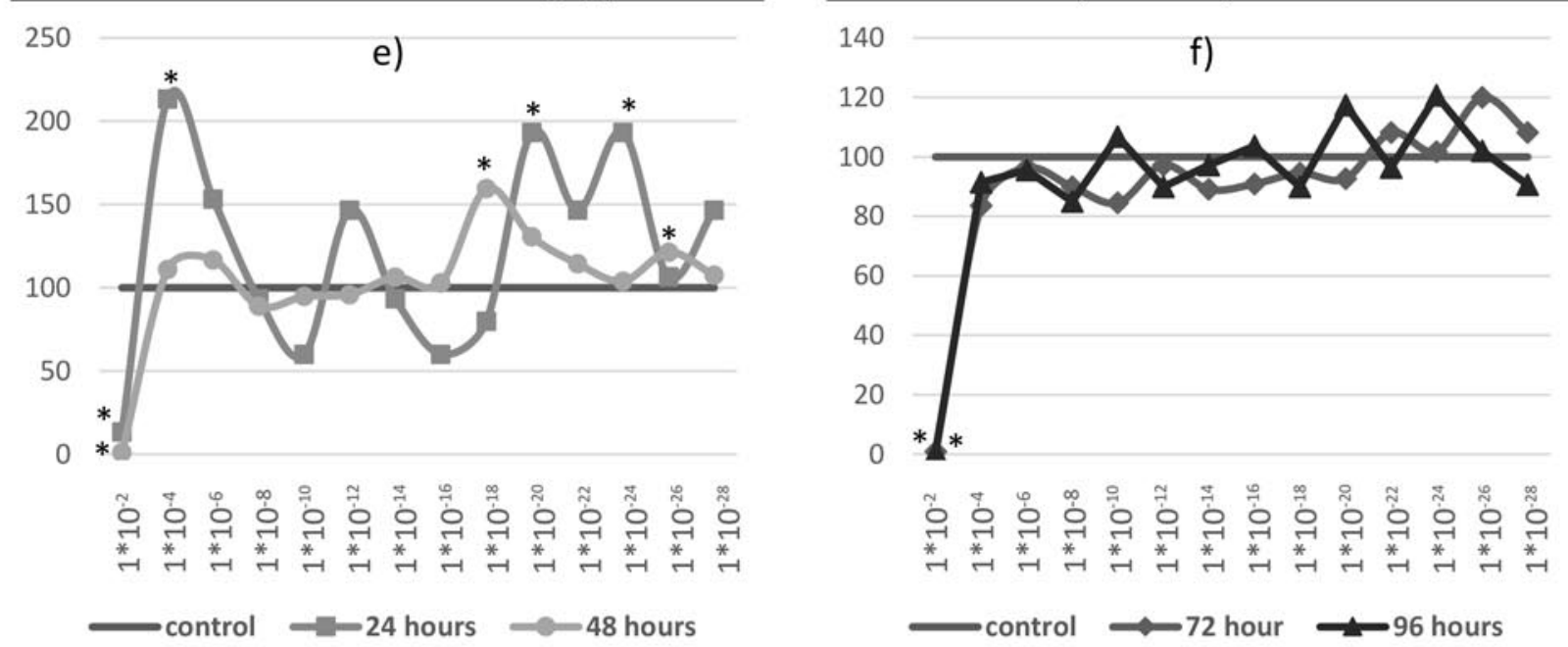

Fig.3. The effect of complexes of 2-methylpyridine-N-oxide with organic acids and metal salts on the growth of ciliates in the conditions of chronic experiment (in\%):

a, b) - DG-349a; c, d) - DG-480; e, f) - DG-471 
The effect of PGR DG-471 (complex of Di-2-methylpyridine-N-oxide with $\mathrm{CoI}_{2}$ ) on the growth of the population of ciliates Tetrahymena pyriformis $\mathrm{W}$ depending on the concentration and time of action is shown in Fig. 3 (e, f).

As can be seen from Fig. 3 (e, f), DG-471 at a concentration of $1 \times 10^{-2} \mathrm{M}$ depending on the time of action has a pronounced toxic effect on the population of ciliates, which is manifested by inhibition of ciliate growth in the lag phase by $86,67 \%$, in other growth phases - at 98,84\%-99, $19 \%$.

In the lag phase, inhibition of ciliate growth was also observed at concentrations of $1 \times 10^{-10} \mathrm{M}$, $1 \times 10^{-16} \mathrm{M}$ and $1 \times 10^{-18} \mathrm{M}$ by $40,00 \%, 40,00 \%$ and $20,00 \%$, respectively. The growth stimulation was observed in concentrations of $1 \times 10^{-4} \mathrm{M}$, $1 \times 10^{-6} \mathrm{M}, 1 \times 10^{-12} \mathrm{M}, 1 \times 10^{-20} \mathrm{M}, 1 \times 10^{-22} \mathrm{M}$, $1 \times 10^{-24} \mathrm{M}$, and $1 \times 10^{-28} \mathrm{M}$, with the greatest effect in concentrations of $1 \times 10^{-4} \mathrm{M}$ $(113,33 \%), 1 \times 10^{-20} \mathrm{M}(93,33 \%)$ and $1 \times 10^{-24} \mathrm{M}$ $(93,33 \%)$.

In the logarithmic growth phase in the concentration range of $1 \times 10^{-4} \mathrm{M}$ to $1 \times 10^{-6}, \mathrm{M}$, as well as $1 \times 10^{-22} \mathrm{M}, 1 \times 10^{-24} \mathrm{M}, 1 \times 10^{-28} \mathrm{M}$ significant changes in the growth of ciliates were not detected. In other cases, stimulation of ciliate growth had the greatest effect at a concentration of $1 \times 10^{-18} \mathrm{M}(59,54 \%)$.

In the stationary phase of growth (72 and $96 \mathrm{~h}$ ) in some concentrations changes in relation to control were not detected, or insignificant growth inhibition was observed, which did not exceed $16,36 \%$. Stimulation of ciliate growth occurred at the level of ultra-low doses and was mild (up to $20,00 \%$ ).

Thus, DG-471 at a concentration of $1 \times 10^{-2} \mathrm{M}$ in all phases of growth has a pronounced toxic effect. However, lower concentrations are characterized by a stimulating effect on the growth of the ciliate population, with the most pronounced effect in the lag phase at concentrations of $1 \times 10^{-4} \mathrm{M}, 1 \times 10^{-20} \mathrm{M}, 1 \times 10^{-24} \mathrm{M}$ and the logarithmic growth phase at a concentration of $1 \times 10^{-18} \mathrm{M}$.

The change in the direction of the effect was observed at the level of high, low and ultralow concentrations. The growth of the ciliate population depending on the concentrations and time of exposure was polymodal in nature.

Comparison of the structure of the studied PGR and the identified effects on the growth of ciliate populations under chronic exposure shows that the growth inhibition at a concentration of $1 \times 10^{-2} \mathrm{M}$ investigated complexes of methyl derivatives of pyridine- $\mathrm{N}$-oxide with metal salts $\mathrm{ZnCl}_{2}, \mathrm{ZnI}_{2}, \mathrm{CoCl}_{2}, \mathrm{CoI}_{2}$ (DG-377, DG-380, DG-387, DG-471, DG-480) are more toxic than complexes with organic acids - succinic or maleic (DG-361a, DG-361, DG-362, DG-349a). This confirms the fact that the inhibition of population growth of ciliates at a concentration of $1 \times 10^{-2}$ $M$ under the influence of complexes with organic acids was greatest mainly in the lag phase of ciliate growth (from $37,50 \%$ to $76,62 \%$ ); for complexes of methyl derivatives of pyridine-N-oxide with metal salts in the lag phase, inhibition of ciliate population growth was the smallest (from $72,09 \%$ to $88,73 \%$ ) for DG-480, DG-377 and DG-471 and the largest (by $100 \%$ ) for DG-380 and DG-387. At this concentration, in the logarithmic and stationary phases of growth of the ciliate population, a complete loss of viability of ciliates was observed under the influence of all investigated complexes of methyl derivatives of pyridine-N-oxide with metal salts. The results obtained are well comparable with the data of acute toxicity of the studied PGRs for ciliates in concentrations of the corresponding $\mathrm{LC}_{50}$ [27]. It follows from this work that under the influence of complexes of methyl derivatives of pyridine-N-oxide with metal salts more pronounced functional and morphostructural changes of ciliates (reduction of movement speed and energy expenditure, change of body shape, structure disturbance and cell lysis) were observed under the influence of complexes of methyl derivatives of pyridine- $\mathrm{N}$-oxide with organic acids.

In the range of concentrations from $1 \times 10^{-4} \mathrm{M}$ to $1 \times 10^{-26} \mathrm{M}$ for the studied PGRs, the nature of the growth of the ciliate population did not depend on the concentration and growth phase (time of action). All investigated substances were characterized by both inhibition and stimulation of growth. These effects were manifested in the range of high, low and ultralow concentrations and did not depend on the growth phase of ciliates. The growth of the ciliate population depending on the concentrations of the studied substances and the exposure time was polymodal in nature.

The direction and severity of the effect for PGR DG-361a, DG-361, DG-377, DG-387, DG-480, DG-349a is characterized by a pro- 
nounced inhibition of ciliate growth and weak or moderate growth stimulation. Preferably a pronounced stimulating effect and a weak inhibitory effect is characteristic of DG-362, DG-380 and DG-471.

The obtained results of research on the absence of dependence "concentration-time effect", diversity of action, the presence of a more pronounced effect at low and ultra-low concentrations of the studied new methyl derivatives of pyridine- $\mathrm{N}$-oxide are consistent with the literature data on plant growth stimulants Ivin and Triman used in the agriculture of Ukraine [13].

\section{Conclusions}

1. Under conditions of chronic exposure to the population of ciliates Tetrahymena pyriformis $\mathrm{W}$, the rate of growth inhibition at a concentration of $1 \times 10^{-2} \mathrm{M}$, studied complexes: DG-377 (Di-2,6-dimethylpyridine-Noxide with $\mathrm{ZnCl}_{2}$ ), DG-380 (2,6-dimethylpyridine-N-oxide with $\mathrm{ZnI}_{2}$ ), DG-387 (Di2,6-dimethylpyridine-N-oxide- with $\mathrm{CoCl}_{2}$ ), DG-480 (2-methylpyridine-N-oxide with $\mathrm{CoCl}_{2}$ ), DG-471 (Di-2-methylpyridine-Noxide with $\mathrm{CoI}_{2}$ ) are more toxic than similar complexes with organic acids - DG-361a (2,6-dimethylpyridine- $\mathrm{N}$-oxide- with succinic acid), DG-361 (Di-2,6-dimethylpyridine-Noxide with succinic acid), DG-362 (2,6dimethylpyridine-N-oxide with maleic acid), DG-349a (2-methylpyridine-N-oxide with succinic acid).

2. In the range of concentrations from $1 \times 10^{-4} \mathrm{M}$ to $1 \times 10^{-28} \mathrm{M}$, regardless of the concentration and time of action, there is both inhibition and induction of growth of the ciliate population. The change in the direction of the effect occurred at the level of high, low and ultralow concentrations. The growth of the ciliate population depending on the concentrations of the studied substances and the exposure time was polymodal in nature.

3. The direction and severity of the effect on the growth of the population of ciliates for DG-361a, DG-361, DG-377, DG-387, DG349a and DG-480 is characterized mainly by an inhibitory effect. The stimulating effect was observed in some phases of growth and was moderate or weak. DG-362, DG-380 and DG-471 are characterized mainly by a more pronounced stimulation of population growth of ciliates.
1. Burlakova YeB. Effekt sverkhmalykh doz. Vestnik Rossiyskoy Akademii Nauk. 1994;64(5):425-31.

2. Burlakova YeB, Goloshchapov AN, Gorbunova NV. Osobennosti biologicheskogo deystviya malykh doz oblucheniya. Radiatsionnaya biologiya. Radioekologiya. 1996;36(4):610-31.

3. Belov VV, Mal'tseva EL, Pal'mina NP. Vliianie alphatokoferola $\mathrm{v}$ shirokom spektre kontsentratsiu na strukturnye kharakteristiki membran éndoplazmaticheskogo retikuluma kletok pecheni mysher in vitro [The effect of alphatocopherol in a wide range of concentrations on the structural features of the lipid bilayer regions of endoplasmic reticulum membranes in the mouse liver cells in vitro]. Radiats Biol Radioecol. 2003 May-Jun; 43(3): 306-9. Russian. PMID: 12881984.

4. Zhernovkov VYe, Bogdanova NG, Lelekova TV, Pal'mina NP. Strukturnyye izmeneniya v membranakh endoplazmaticheskogo retikuluma pri deystvii sverkhmalykh doz tiroliberina in vitro. Biologicheskiye membrany. 2005;22(5):388-95.

5. Shafran LM, Mokyenko AV, Petrenko NF, Gozhenko AI, Nasibullin B.A. K obosnovaniyu gormezisa kak fundamental'noy biomeditsinskoy paradigmy (obzor literatury i rezul'tatov sobstvennykh issledovaniy). Sovremennye problemy toksykolohyy. 2010:2-3:13-23. Russian

6. Martynov AI, Golubeva NN, Zelenova ZV. Vliyaniye antropogennykh faktorov khimicheskoy prirody na immunnuyu sistemu cheloveka i zhivotnykh. [Influence of anthropogenic chemical agents on human and animal immune system]. Medytsyna ekstremal'nykh sytuatsyj. 2013;1(43):50-75. Russian
7. Vasetska OP, Zhminko PG. «Paradoksal'nye» éffekty v toksykolohyy, mekhanyzmy y metodycheskye podkhody k ykh prohnozyrovanyyu (po dannym lyteratury y sobstvennykh yssledovanyy) ["Paradoxical" effects in toxicology, mechanisms and methodological approaches to prediction (according to the literature and our own research)]. Suchasni problemy toksykolohiyi, kharchovoyi ta khimichnoyi bezpeky. 2015;1/2(68/69):54-66.

8. Zhuravskaia AN. Biologicheskiye effekty malykh doz ioniziruyushchikh izlucheniy (obzor). [Biological effects of small doses of ionizing radiation (Review)]. Nauka y obrazovanye. 2016;2:94-102. Russia

9. Yerofeyeva YeA. Nemonotonnoye izmeneniye fiziologobiokhimicheskikh pokazateley prorostkov pshenitsy pri deystvii svintsa v shirokom diapazone kontsentratsiy [Nonmonotonous changes in physiologcal and biochemical indicators of wheat seedlings at exposure to lead in a wide dose range]. Toxicological review. 2013;2(119):47-50. Russia

10. Erofeeva EA. Hormesis and paradoxical effects of pea (Pisum sativum L.) parameters upon exposure to formaldehyde in a wide range of doses Ecotoxicology. 2018 Jul;27(5):569-77. doi: 10.1007/s10646-018-1928-2.

11. Bogatyrenko TN, Redkozubova GP, Kondratov AA, Antonovskiy VL, Burlakova YeB.. Vliyaniye organicheskikh peroksidov na rost kul'tiviruyemykh kletok vysshikh rasteniy. Biofizika. 1989;34(2):327.

12. Ponomarenko SP. Regulyatory rosta rasteniy. Institut bioorganicheskoy khimii. Kiev, 2003. S 319. 
13. Zhmínko OP, Prodanchuk MG. (2002). Vpliv deyakikh pokhídnikh N-oksid píridinu na ríst populyatsiî ínfuzoríy Tetrahymena pyriformis W. [Influence of derivative Noxide pyridine on growth of infusorians population Tetrahymena pyriformis W]. Sovremennyye problemy toksikologii. 2002; 2:33-37.

14. Zhminko OP, Nadtochij OP, Prodanchuk MG. Vplyv ivinu na bilkovyj obmin schuriv pry subkhronichnomu nadkhodzhenni do organizmu. Sovremennyye problemy toksykologii. 2003;2:85-90.

15. Zhminko OP. Vliyuvannya deyakykh vyrobnychykh Noksydnykh pirydyniv na membrany mitokhondriy pechenoho krysu pry subkhronichnomu peroral'nomu vozdeystvyy. Sovremennyye problemy toksykologii. 2003;1:50-4.

16. Lototska-Dudyk UB, Krupka NO. Paradoksal'na toksychnist' yak aktual'nyy napryamok suchasnoyi toksykolohiyi [Paradoxum toxicity as the actual tendency of modern toxicology]. Zbírnik Aktual'ní problemi profílaktichnoï meditsini. 2018;1,2(15):8-14.

17. Helmut Sies. Oxidative Stress: Eustress and Distress in Redox Homeostasis. Stress: Physiology, Biochemistry, and Pathology, Handbook of Stress Series. 2019;3:153-63. DOI: 10.1016/B978-0-12-813146-6.00013-8

18. Szumiel I. Ionizing radiation-induced oxidative stress, epigenetic changes and genomic instability: the pivotal role of mitochondria. Int J Radiat Biol. 2015;91:1e12. DOI: 10.3109/09553002.2014.934929

19. Kim SA, Lee YM, Choi JY, Jacobs Jr DR, Lee DH. Evolutionarily adapted hormesis-inducing stressors can be a practical solution to mitigate harmful effects of chronic exposure to low dose chemical mixtures. Environ Pollut. 2017;233:725-34. DOI: 10.1016/j.envpol.2017.10.124

20. Sies H, Feinendegen LE. Radiation Hormesis: the link to nanomolar hydrogen peroxide. Antioxid Redox Signal. 2017;27:596-8. DOI: 10.1089/ars.2017.7233

21. Davies KJ. Adaptive homeostasis. Mol Aspects Med. 2016;49:1-7. DOI: 10.1016/j.mam.2016.04.007

22. Kurvet I, Juganson K, Vija H, Sihtmäe M, Blinova I, Syvertsen-Wiig G, Kahru A. Toxicity of Nine (Doped) Rare Earth Metal Oxides and Respective Individual Metals to Aquatic Microorganisms Vibrio fischeri and Tetrahymena thermophila. Materials. 2017; 10(7):754. DOI: 10.3390/ma10070754

23. Maurya R, Dubey K, Singh D, Jain AK, Pandey AK. Effect of difenoconazole fungicide on physiological responses and ultrastructural modifications in model organism Tetrahymena pyriformis. Ecotoxicology and Environmental Safety. 2019; 182:109375. DOI: 10.1016/j.ecoenv.2019.109375

24. Maurya R, Pandey AK. Importance of protozoa Tetrahymena in toxicological studies: A review. Science of The Total Environment. 2020;741:140058. DOI: 10.1016/j.scitotenv.2020.140058

25. Papa Daouda Mar, BouchraEl Khalfi, Abdelaziz Soukr. Protective effect of oregano and sage essentials oils against the effect of extracellular H2O2 and SNP in Tetrahymena thermophila and Tetrahymena pyriformis. Journal of King Saud University-Science. 2020;32(1):279-87. DOI: 10.1016/j.jksus.2018.05.005

26. Bogdan AS. Kompleksnaya biologicheskaya otsenka ob"yektov prirodnogo i iskusstvennogo proiskhozhdeniya na Tetrahymena pyriformis (metodicheskiye rekomendatsii), Minsk. 1996. 19p.

27. Vasetska OP. Morpho-functional changes of Tetrahymena pyriformis $\mathrm{W}$ under the influence of plant growth regulators - N-oxide derivatives of pyridine. Ukranian journal of modern problems of toxicology. 2020;3(90):40-51.

\title{
ХРОНІЧНА ТОКСИЧНІСТЬ НОВИХ ПОХІДНИХ N-ОКСИД ПІРИДИНУ ДЛЯ IHФУЗОРIЙ TETRAHYMENA PYRIFORMIS W, ВИЗНАЧЕННЯ ЗАЛЕЖНОСТI «СТРУКТУРА-ТОКСИЧНІСТЬ», «КОНЦЕНТРАЦІЯ-ЧАС-ЕФЕКТ
}

О.П. Васецька

Державне підприємство «Науковий центр превентивної токсикології, харчової та хімічної безпеки імені академіка Л.І. Медведя Міністерства охорони здоров’я України», м. Киї, Україна

\begin{abstract}
PЕЗЮМЕ. У науковій літературі є значна кількість робіт щодо нелінійних («парадоксальних») ефектів, але їх токсикологічна значимість для організму ще недостатньо з'ясована. Регулятори росту рослин є біологічно активними речовинами на рівні низьких і наднизьких доз і концентрацій, вони масштабно застосовуються в сільському господарстві. На сьогодні недостатньо вивчено механізми їхньої токсичної і специфічної дії на організм, наявність «парадоксальних» ефектів на низькому рівні доз. Отжее, актуальним є подальще поглиблене дослідження залежнності «концентрація-час-ефект» за умов хронічного впливу на організм, що матиме важливе значення для розуміння загальнобіологічних процесів, розробки підходів щодо гігієнічного нормування та оцінки ризику для здоров'я людини і нецільових об'єктів навколишнього середовища.

Мета роботи. Визначити залежність “структура-токсичність”, „концентрація-час-ефект” регуляторів росту рослин похідних $N$-оксид піридину за умов хронічного впливу на організм інфузорій Tetrahymena pyriformis $W$.

Матеріали та методи. Об'єктом досліджень були комплекси метильних похідних $N$-оксид піридину з органічними кислотами та солями металів. Дослідження проведені на інфузоріях Tetrahymеnаруriformis $W$ у стаціонарній фазі росту. Хронічну дію регуляторів росту рослин на інфузорії вивчали в 96-годинному експерименті у діапазоні концентрацій від $1 \times 10^{-2}$ М до $1 \times 10^{-28}$ М. Початкова кількість інфузорій у пробі становила 20000 особин/мл культурального середовища. Проби інкубували у сухоповітряному термостаті при $25^{\circ} \mathrm{C}$. Через 24, 48, 72, 96 годин визначали чисельність інфузорій у різних фазах росту. Експерименти проведені в чотирьох повторностях. Результати досліджень піддавали математичній обробці методами варіаційної статистики з використанням стандартного пакету програмного забезпечення Місrоsоft ${ }^{\circledR}$ Office Excell 2010.

Результати. Показано, що в концентрації $1 \times 10^{-2}$ М досліджені комплекси метильних похідних $N$-оксидпіридину з солями металів є більш токсичними, ніж з органічними кислотами. У діапазоні концентрацій від $1 \times 10^{-4}$ М до $1 \times 10^{-28} \mathrm{M}$ залежності «концентрація-час-ефект» не виявлено. Незалежно від концентрації і часу дії спостерігалось як інгібування, так й індукція росту популяції інфузорій. Зміна спрямованості ефекту спостерігалась на рівні високих, низьких і наднизьких кониентрацій.
\end{abstract}


Висновки. 1. За умов хронічного впливу на організм популяції інфузорій Tetrahyтепаругіformis $W$, за показником пригнічення росту в концентрації $1 \times 10^{-2} \mathrm{M}$, досліджені комплекси ДГ-377 (Ди-N-оксид-2,6-диметилпіридину з $\mathrm{ZnCl}$ ), ДГ-380 (N-оксид-2,6-диметилпіридину з ZnI $)$, ДГ-387 (Ди-N-оксид-2,6-диметилпіридину з $\left.\mathrm{CoCl}_{2}\right)$, ДГ-480 (N-оксид-2-метил піридину з $\mathrm{CoCl}_{2}$ ), ДГ-471 (Ди-N-оксид-2-метилпіридину з $\mathrm{CoI}_{2}$ ) є більш токсичними, ніж аналогічні комплекси з органічними кислотами - ДГ-361a ( $N$-оксид-2,6-диметилпіридину з бурштиновою кислотою), ДГ-361 (Ди- $N$-оксид-2,6-диметилпіридину з бурштиновою кислотою), ДГ-362 (Ди-N-оксид-2,6-диметилпіридину з малеїновою кислотою), ДГ-349a (Nоксид-2-метилпіридину з бурштиновою кислотою). 2. У діапазоні концентрацій від $1 \times 10^{-4} \mathrm{M}$ до $1 \times 10^{-28} \mathrm{M}$, незалежно від концентрації і часу дії спостерігається як інгібування, так й індукція росту популяції інфузорій. Зміна спрямованості ефекту спостерігалась на рівні високих, низьких і наднизьких концентрацій. Ріст популяції інфузорій залежно від концентрацій досліджених речовин і часу впливу, мав полімодальний характер. 3. За спрямованістю і виразністю ефекту на ріст популяції інфузорій для ДГ-361а, ДГ-361, ДГ-377, ДГ-387, ДГ-349а і ДГ-480 характерним є переважно інгібуючий ефект. Стимулюючий ефект спостерігався в окремих фазах росту і був помірно або слабко вираженим. Для ДГ-362, ДГ-380 і ДГ471 характерним є переважно виражена стимуляція росту популяції інфузорій.

Ключові слова: Метильні похідні N-оксидпіридину, інфузорії, «структура-токсичність», «концентрація-час-ефект»

\section{ХРОНИЧЕСКАЯ ТОКСИЧНОСТЬ НОВЫХ ПРОИЗВОДНЫХ N-ОКСИД ПИРИДИНА ДЛЯ ИНФУЗОРИЙ TЕTRAНYMЕNA PYRIFORMIS W, OПРЕДЕЛЕНИЕ ЗАВИСИМОСТИ «СТРУКТУРА-ТОКСИЧНОСТЬ», «КОНЦЕНТРАЦИЯ-ВРЕМЯ-ЭФФЕКТ \\ О.П. Васецкая}

Государственное предприятие «Научный центр превентивной токсикологии, пищевой и химической безопасности имени академика Л.И. Медведя Министерства здравоохранения Украины», г. Киев, Украина

PЕЗЮМЕ. Несмотря на то, что в научной литературе имеется значительное количество работ о нелинейных («парадоксальных») эффектах, их токсикологическая значимость для организма еще недостаточно выяснена. Поскольку регуляторы роста растений являются биологически активными веществами на уровне низких и сверхнизких доз и концентраций, а также учитывая их масштабность применения в сельском хозяйстве, недостаточную изученность механизмов их токсического и специфического действия на организм, наличие «парадоксальных» эффектов на низком уровне доз, актуальным является дальнейшее углубленное исследование зависимости «концентрация-время-эффект» в условиях хронического воздействия на организм, что будет иметь важное значение для понимания общебиологических процессов, разработки подходов к гигиеническому нормированию и оценке риска для здоровья человека и нецелевых объектов окружающей среды.

Цель работы. Определить зависимость «структура-токсичность», «концентрация-время-эффект» регуляторов роста растений - производных $N$-оксид пиридина в условиях хронического воздействия на организм инфузорий Tetrahymеnа ругіformis $W$.

Материалы и методы. Объектом исследований были комплексы метильных производных N-оксид пиридина с органическими кислотами и солями металлов. Исследования проведены на инфузориях Tetrahymena pyriformis $W$ в стационарной фазе роста. Хроническое действие регуляторов роста растений на инфузории изучали в 96-часовом эксперименте в диапазоне концентраций от $1 \times 10^{-2}$ М до $1 \times 10^{-28}$ М. Начальное количество инфузорий в пробе составляла 20000 особей/мл культуральной среды. Пробы инкубировали в суховоздушном термостате при $25^{\circ} \mathrm{C}$. Через 24, 48, 72, 96 часов определяли численность инфузорий в различных фазах роста. Эксперименты проведены в четырех повторностях. Результаты исследований подвергали математической обработке методами вариационной статистики с помощью Microsoft ${ }^{\circledR}$ Office Excell 2010.

Результаты. Показано, что в концентрации $1 \times 10^{-2}$ М исследованые комплексы метильных производных $N$-оксидпиридина с солями металлов являются более токсичными, чем с органическими кислотами. В диапазоне концентраций от $1 \times 10^{-4}$ М до $1 \times 10^{-28}$ М зависимости «концентрация-время-эффект» не обнаружено. Независимо от концентрации и времени воздействия наблюдалось как ингибирование, так и индукция роста популяции инфузорий. Изменение направленности эффекта наблюдалось на уровне высоких, низких и сверхнизких концентраций.

Выводы. 1. В условиях хронического воздействия на организм популяции инфузорий Tetrahymena pyriformis $W$, nо показателю подавления роста в концентрации $1 \times 10^{-2} \mathrm{M}$, исследованные комплексы ДГ-377 (Ди- $N$-оксид-2,6-диметилпиридина с $\mathrm{ZnCl}_{2}$ ), ДГ-380 (N-оксид-2,6-диметилпиридина с ZnI 2), ДГ-387 (Ди-N-оксид-2,6-диметилпиридина с CоCl $)$, ДГ-480 ( $N$-оксид-2-метил пиридина с $\mathrm{CoCl}_{2}$ ), ДГ-471 (Ди-N-оксид-2-метилпиридина с $\mathrm{CoI}_{2}$ ) более токсичны, чем аналогичные комплексы с органическими кислотами - ДГ-триста шестьдесят первой ( $N$-оксид-2,6-диметилпиридина с янтарной кислотой), ДГ-361 (Ди-N-оксид-2,6-диметилпиридина с янтарной кислотой), ДГ-362 (Ди- $N$-оксид-2,6-диметилпиридина с малеиновой кислотой), ДГ-триста сорок девятом ( $N$-оксид-2-метилпиридина с янтарной кислотой).

2. В диапазоне концентраций от $1 \times 10^{-4}$ М до $1 \times 10^{-28}$ М, независимо от концентрации и времени воздействия наблюдается как ингибирование, так и индукция роста популяции инфузорий. Изменение направленности эффекта наблюдалось на уровне высоких, низких и сверхнизких концентраций. Рост популяции инфузорий, в зависимости от концентраций исследованных веществ и времени воздействия, имел полимодальный характер.

3. По направленности и выразительности эффекта на рост популяции инфузорий для ДГ-361а, ДГ-361, ДГ-377, ДГ-387, ДГ-349а и ДГ-480 характерно преимущественно ингибирующий эффект. Стимулирующий эффект наблюдался в отдельных фазах роста и был умеренно или слабо выраженным. Для ДГ-362, ДГ-380 и ДГ-471 характерным является преимущественно выраженная стимуляция роста популяции инфузорий.

Ключевые слова. Метильные производные $N$-оксидпиридину, инфузории, «структура-токсичность», «концентрациявремя-эффект». 